DOI: $10.17805 /$ zpu.2016.1.10

\title{
Дихотомия “детства - взрослости» в представлениях детей (в контексте социально-экономического положения их родительских семей)
}

\author{
А. А. БЕСЧАСНАЯ \\ (САНКТ-ПЕТЕРБУРГСКИЙ ГОСУДАРСТВЕННЫЙ АРХИТЕКТУРНО-СТРОИТЕЛЬНЫЙ \\ УНИВЕРСИТЕТ)
}

В статье представлены результаты авторского исследования феномена детства глазами детей как дихотомии взрослости в контексте социально-экономического фактора. Детство как социальный феномен, так же как и многие современные социальные явления, подвержено изменениям под воздействием целого ряда факторов. Среди множества детерминант, определяющих индивидуальный образ детства, характер прохождения психологических кризисов и переход во взрослость, выделяются социально-экономическое положение семьи, особенности воспитания и социализации детей в семье.

Для определения представлений детей о детстве и взрослости в зависимости от социально-экономических условий воспитания и социализации в семье автор предприняла в 2007 г. в Санкт-Петербурге и Ленинградской области социально-психологическое исследование методом фокус-групп с участием детей 6-7 лет, воспитывающихся в семьях с различным уровнем материального благополучия.

Ответы детей продемонстрировали двойственность отношения к ним со стороны окружающих и, соответственно, их представлений о самих себе как представителей мира детства и мира взрослых. Ощущение себя «детьми» или «взрослыми» в социуме у детей складывается из элементов повседневных социальных практик: игровой деятельности, взаимодействия со сверстниками и с представителями старшего поколения, информационного контента общения.

Для детей, проживающих в благополучных социально-экономических условиях, в большей степени характерен диссонанс в идентификации себя к миру детей или миру взрослых, так как они оказываются в эпицентре противоречий - декларирование их «взрослыми» одновременно с ограничением их деятельности и коммуникативного пространства для самореализации. Повседневность же детей из других социально-экономических слоев содержит социальные практики с сокращением или отсутствием контроля со стороны взрослых, что также обладает потенциалом противоречия в самосознании и самопричислении детей.

Ключевые слова: детство; взрослость; дети; фокус-группа; семья; социально-экономический фактор

\section{ВВЕАЕНИЕ}

Совеменные социологические исследования рассматривают общественные проблемы и социальные трансформации сквозь призму проблем отдельного человека, анализа индивидуального мировоззрения, мотивов, «жизненного мира», «личного пространства», «социальных практик» и «габитуса». Фундаментальный вклад в формирование и развитие данного подхода внесли представители «понимающей социологии» (М. Вебер), символического интеракционизма (Г. Блумер, Ч. Х. Кули, У. А. Тома, Аж. Г. МиА), феноменологической социологии (А. Щюц), этнометодологии (Г. Гарфинкель), модернизма и постмодернизма (П. Бурдье, Э. Гидденс, 3. Бауман, Ж. Бодрийяра) и др. Аанные направления создали методологический базис качественным социологическим исследованиям.

Методология качественных социологических исследований позволяет учитывать психофизиологические особенности и социальный опыт индивидов, в том числе детей. Образ мира, по словам российского психолога А. Н. Аеонтьева, есть единство по- 
знания и эмоционально-потребностной сферы индивида, включающее в себя значения, смыслы, впечатления (Иеонтьев, 1984: 164).

Использование методов исследования качественной методологии (фокус-группа, case-study, глубинные интервью, биографическое описание и т. д.) позволяет получить закрытую информацию, основанную на личных чувствах респондента, иррациональных проявлениях, способах упорядочения и структурирования социальной реальности, конструировании респондентами собственного социального мира (Фоломеева, 2003: 87-88; см. также: Безрогов, 2007). Посредством качественных методов определяется восприятие индивидом объекта и отношение к нему, формируется индивидуальный репрезентативный мир. Репрезентативный мир - это сочетание психических репрезентаций желаний, чувств, воспоминаний человека, его представлений и символов об окружающем мире. В процессе своего развития ребенок создает целый комплекс схем, или репрезентаций, которые структурируют входящую сенсорную информацию в осмыслении образа восприятия (Васильева, 2006: 74) и которые образуют картину мира его личности. С целью получения подобной информации әффективно использовать метод фокус-группы, который обладает высоким исследовательским потенциалом в раскрытии представлений, образующих детское мировоззрение.

Как основную проблему исследования автор выдвинула определение суждений детей о детстве и взрослости в зависимости от социально-экономических условий воспитания и социализации в семье.

Материальное положение, культура взаимодействия между поколениями, характер отношений между взрослыми и детьми, стили воспитания и социализации определяют смыслы и значения социальных фактов социальной реальности (Аемоз, 2000). Эти смыслы и значения выступают опорными точками для индивидов в вопросах репрезентации, а также в конструировании мира и отношений с другими индивидуумами в обществе в настоящем и будущем. Моделирование мира детьми, исходя из личных социальных практик в социальном пространстве, создает габитус их жизнедеятельности и социальной действительности. В связи с этим представляется интересным выявление особенностей формирования у детей представлений о возрастной дифференциации и собственной интеграции в возрастную структуру общества. Аанные представления являются одними из первейших в формировании идентичности и личности человека.

\section{СПЕЦИФИКА «ЖИЗНЕННОГО МИРА» АЕТЕЙ}

Мировоззрение и самосознание ребенка формируются в определенной «социальной ситуации развития», неотъемлемой частью которой является стремление стать взрослыми, приобщиться к жизни и деятельности взрослых. Условия социализации и воспитания, выражаемые в социально-экономических, культурных, национальных, демографических, социально-психологических факторах, являются фоном формирования самосознания ребенка (Емельянова, 2015; Breland-Noble, 2014). Специфика «жизненного мира» и «социальных практик» неуклонно множится из-за увеличения числа и разнообразия социализирующих факторов, модернизации среды жизнедеятельности, трансформации характера отношений, изменения габитуса индивидов.

Рассмотрение детства как социального феномена невозможно вне контекста жизни, обстоятельств развития и формирования личности ребенка. При условии естественного и нормального хода развития событий (а именно - рождения и воспитания ребенка) основным социальным институтом социализации ребенка является семья. 
Семья представляет собой промежуточный этап в освоении более масштабной среды жизнедеятельности человека - общества. Поэтому в жизни ребенка семья выступает в качестве проводника и «буфера» воздействий общества. Непосредственно в семье формируется современный образ детства.

Трансформации социального института семьи в период индустриализма, распространения урбанизированного образа жизни и продолжившиеся изменения в постиндустриальную эпоху пошатнули «традиционные» представления о семье и браке, преобразовали норму, «трансформировали интимность» (Гидденс, 2004). В связи с быстротечностью событий дети оказались вовлеченными в данные изменения и как зрители, и как участники. Стремительность изменений в обществе усложняет процесс социализации детей, так как «точки опоры» в формировании человека как личности, формировании его картины мира и мировоззрения приобретают характер «сиюминутности» (Бауман, 2008: 135) и зыбкости. Современные дети, с одной стороны, более активны во взаимодействиях с окружающим миром, а с другой - в обществе среди молодежи наблюдается затянувшийся инфантилизм.

Предполагается, что жизненный мир детей, их личное социальное пространство закрепляются и воспроизводятся, пройдя сквозь призму детского восприятия, воспитания и социализации, формируя, таким образом, образ детства и взрослого мира. По мнению А. Ю. Солнышкова, «человек одновременно является и основным инструментом познания и оценки внешней действительности, и методологом дичной “программы познания", и “сценаристом" своей субъективной картины реальности» (Солнышков, 2014: 158). Культурно-исторический фон формирования детства как социального феномена демонстрирует нам модель мира взрослых как мира возможностей, прав, приобретений (разного характера), пропуском в который являются инициации. Как отмечает А. И. Фельдштейн, «детство отличается постоянной ориентацией на Взрослый Мир, потребностью приобщения к Социуму» (Фельдштейн, 2004: 152). Аети выступают в качестве фундамента событий будущего.

\section{ОРГАНИЗАЦИЯ ПРОВЕАЕНИЯ ИССАЕАОВАНИЯ}

Аля изучения сформулированной проблемы автором было проведено в 2007 г. (февраль - апрель) исследование с применением метода фокус-группы. В нем них участвовали дети 7 лет, объединенные в группы по полу по 7-9 человек, из относительно гомогенных по социально-экономическим показателям семей, проживающие в г. СанктПетербурге и $А$ енинградской области (всего 50 детей) ${ }^{1}$. Гомогенность фокус-групп обеспечивалась контингентом дошкольных учреждений, наполнение которых происходило за счет детей, проживающих в окрестностях детского сада. Районы же проживания в результате развития города и распространения урбанистических процессов (уже по исторически сложившейся социальной практике) дифференцированы по социально-экономическим показателям стоимости жилья, доступности, характеру и стоимости товаров и услуг, экологическим условиям проживания, престижности жилого района. Аанные социально-экономические показатели явились «социальными фильтрами» в формировании гомогенности населения районов проживания. Следовательно, дифференциация детских фокус-групп происходила по признакам расположения детских дошкольных учреждений и проживающего в данных районах основного контингента, пользующегося услугами этих детских садов. Таким образом, фокус-группы по месторасположению детских учреждений и очевидному социально-экономическому положению детей и их семей образовали следующую группировку: 
Группа А - дети-респонденты, проживающие в центральном и престижном районе города Санкт-Петербурга (Петроградский район г. Санкт-Петербурга).

Группа В - дети-респонденты, проживающие в районе, имеющем промежуточное положение по отношению к центру и окраине Санкт-Петербурга (район Купчино г. Санкт-Петербурга).

Группа C - дети-респонденты, проживающие в пригороде Санкт-Петербурга (Гатчинский район

В таблице приведены характеристики фокус-групп, демонстрирующие нам количественный и половой состав представленной классификации.

ХАРАКТЕРИСТИКА ФОКУС-ГРУПП

THE CHARACTERISTICS OF FOCUS GROUPS

\begin{tabular}{|l|c|c|c|c|c|c|}
\hline \multirow{2}{*}{ Фокус-группь } & \multicolumn{5}{|c|}{ Пол } \\
\cline { 2 - 7 } & мальчики & девочки & мальчики & девочки & мальчики & девочки \\
\hline $\begin{array}{l}\text { Группа А } \\
\text { Группа В } \\
\text { Группа С }\end{array}$ & 8 & 9 & & & & \\
\hline Всего детей по группам & & & 9 & 8 & & 9 \\
\hline Всего детей & \multicolumn{2}{|c|}{17} & \multicolumn{2}{|c|}{17} & \multicolumn{2}{c|}{16} \\
\hline
\end{tabular}

Рассмотрим социальные характеристики фокус-групп. Аети, участвовавшие в фокус-группе группы A, посещают детский сад, расположенный в престижном районе города Санкт-Петербурга, который, несмотря на центральное расположение, окружен садово-парковым массивом, отдален от автомобильных трасс, бизнес-центров, суеты центра города. Это дошкольное учреждение находится в непосредственной близости от элитного жилья. Одна из красноречивых характеристик детей, данная персоналом учреждения, заключается в том, что их воспитанники являются выходцами из семей с высоким материальным достатком, где чаще всего работает один из родителей (обычно отец), многие дети кроме посещения детского учреждения получают дополнительно услуги гувернанток.

Группу В образовали дети, живущие в районе города с доминирующим жилым фондом и сферой бытового обслуживания. Контингент жителей района исторически сформирован типичными представителями российского среднего класса: представители работников преуспевающих промышленных предприятий, интеллигенции, средние и мелкие предприниматели. По свидетельству воспитателей этих детских садов, в семьях работают, как правило, оба родителя; они имеют как минимум двух детей, за пределами детского сада детей чаще всего сопровождают дедушки и бабушки.

B группу C вошли дети, живущие в пригороде - поселке городского типа. Этот населенный пункт характеризуется тем, что в нем недостаточное количество рабочих мест (фактически одно предприятие), недорогое жилье, и его молодые жители стремятся найти работу в Санкт-Петербурге с дальнейшим проживанием в нем. Поэтому данный населенный пункт является транзитной зоной для мигрантов дибо для коренных жителей, мечтающих уехать в материально привлекательный крупный город. 
В большинстве семей стабильный доход имеет один из родителей, некоторые родители работают в Санкт-Петербурге, поэтому приезжают к семье и общаются с детьми лишь по выходным. В большинстве семей детей двое и более.

Завершая описание организации исследования, хотелось бы отметить соблюдение автором этических норм и правил проведения фокус-групп с детьми. Об исследовании с участием детей родители были проинформированы. Им сообщили информацию о цели исследования, описали круг исследовательских проблем, пояснили особенность надындивидуальности групповых бесед с детьми и сведений, получения информации как отражения социально-типичных фактов, а не конкретно-индивидуальных. Также родители получили заверение исследователя о недопущении во время проведения фокус-групп рассмотрения вопросов и ситуаций, которые могли бы отрицательно отразиться на достоинстве личности ребенка, его психологическом самочувствии. Исходя из этих же этических соображений, автор избегает указания точного месторасположения детских дошкольных учреждений в Санкт-Петербурге и пригороде.

\section{«MИР АЕТСТВА» И «МИР ВЗРОСАЫХ » \\ $B$ «ЖИЗНЕННОМ МИРЕ» АЕТЕЙ}

Аетство является социальным феноменом, оно имеет культурно-исторические корни и характеристики. Увеличение периода детства и изменение образа детства происходит вместе с развитием общества, продолжительностью жизни человека, увеличением количества знаний, необходимых взрослому человеку для активной жизни в обществе. Ф. Арьес показал, что детство является динамичным феноменом, который трансформируется во времени и в пространстве (Арьес, 1999: 403).

Понимание любого жизненного периода связано не только с биологическим возрастом, но и с теми культурными и социальными значениями, которые ему приписываются в обществе. Как ребенок понимает и воспринимает те смыслы и значения, которые делят мир на «детей» и «взрослых»? В результате исследования дети продемонстрировали, что есть два понимания измерения «детства» и «взрослости» в пределах семьи и за пределами семьи. Авойственность представлений уживается в их сознании и создает фундамент неоднозначности оценок событий и фактов социальной реальности и социальных норм. Согласно мнению большинства детей в семьях, т. е. в пределах первичной социализации, их считают взрослыми (хотя, конечно, в этих ответах обнаруживает себя и детское притязание на признание). Аети указывали, что родители называют их и относятся к ним как к взрослым. Но тут же дети из групп В и С оговариваются, что за пределами дома и семьи, т. е. в рамках вторичного круга социализации, они испытывают на себе отношение как к детям, становясь, таким образом, в глазах окружающих взрослых и в собственных глазах представителями детского мира. Однако дети из группы А высказали мнение о ментальном представлении себя взрослыми в восприятии людьми, старшими по возрасту и не входящими в семейное окружение:

Bопрос: "Кем Вы себл считает - взросльми или детьми?"

Станислав $(\mathrm{A})^{2}$ : «А я для всех взрослый, меня нельзя считать маленьким».

Валентина (А): «Мама сказала, что я взрослая, и купила мне туфли на каблуке. В них я хожу везде».

Ангелина (В): «Меня считают взрослой. Но одна я не гуляю, как взрослые».

Катя (B): «Мы еще дети, потому что мы ходим в детский сад». 
Карина (В): «Нет, нас считают детьми. Потому что мы не такие взрослые. Мы на работу не ходим».

Александр (C): «Я взрослый, потому что мне уже 6 лет».

Евгения (С): «Пока мы ходим в детский сад, мы - дети».

В качестве критериев взрослости дети выделяют большее количество знаний и возможностей, доступность большего количества видов деятельности и наличие собственных детей. Кроме того, частым упоминанием является возможность взрослыми совершать покупки, что, безусловно, является дифференцирующим признаком и свидетельством усвоения детьми потребительских стандартов современного общества, в чем, в свою очередь, проявляется «постмодернистская революция ценностей» (Бауман, 2008: 89):

Bопрос: «Как вы думаете, что отличает взрослого от ребенка?»

Владимир (A): «Взрослый - когда все покупаешь, ухаживаешь, моешь посуду. Взрослые кормят».

София (А) «У взрослых права (водительские. - А. Б.) есть».

Полина (В): «Взрослый может все самостоятельно делать, а ребенок не все».

Аарья (В): «Взрослому можно ходить одному. Маленький может купить с разрешения мамы».

Ааниил (C): «Они (взрослые. - А. Б.) на работу ходят».

Ксения (C): «Взрослый - это когда все можно, и никто не ругает».

Знаковые события жизни детей, интегрирующие их во взрослую жизнь, также демонстрируют дифференцирующий характер их социализации и жизнедеятельности их родительских семей. Несмотря на отсутствие признанных обществом обрядов инициаций (за исключением получения паспорта и, соответственно, официального наделения новоиспеченных граждан всеми правами и видами ответственности), в повседневной жизни детей и семей присутствуют символичные события и обычаи, которые закрепляют принадлежность личности (ребенка) к полу, к культурной среде, к определенному социально-экономическому классу и ознаменовывают в самосознании ребенка и сознании окружающих переход ребенка на качественно новый виток жизненного цикла (Бесчасная, 2007: 125-139).

Вопрос: "Какие действия или события в жизни сделают из вас взросльх людей?"

Максим (A): «Меня считают взрослым, потому что я уже умею водить машину и снегоход».

Татьяна (A): «Мне папа деньги дает, потому что я взрослая».

Алеша (B): «Я буду взрослым после школы».

Слава (B): «После института».

Карина (В): «Когда в институт пойдем, будем взрослыми».

$\Lambda$ ера (C): «Когда работать начнем».

Анн (C): «Когда пойдем в первый класс».

Одним из признаков, дифференцирующих «детство» и «взрослость», а также сопровождающих переход индивида из состояния детства во взрослую жизнь, является наличие и расширение спектра прав, представляющего собой комплекс политических, гражданских, социальных гарантий, закрепленных законом. Безусловно, дети обладают правами, представителями и выразителями которых являются их близкие и родные, а нарушение их прав является поводом для беспокойства и внимания общественности. Ответы детей полностью подтвердили необходимость патронажа и контроля соблюдения прав детей со стороны неравнодушных и ответственных взрослых. В свя- 
зи с недостаточной сформированностью абстрактного и понятийного мышления, а также отсутствием опыта самостоятельного взаимодействия в обществе дети закономерно показали непонимание этого аспекта взрослой жизни. В целом это указывает на зависимый характер жизни детей, в которой они выступают исполнителями решений и воли взрослых, и повышает ответственность старших за принимаемые ими решения. У детей вызвали затруднения вопросы о правах, и без дополнительных пояснений интервьюера о том, что наличие прав предполагает возможность принимать решения, исполнять желаемое и т. А., им тяжело было сориентироваться в этом аспекте жизни.

Bonpoc: "У вас есть права?"

Андрей (A): «У моих родителей есть права, а у меня пока нет».

Катя (B): «У меня нет прав».

Константин (C): «Я не помню, есть ли у меня права».

Необходимость в заботе и опеке со стороны взрослых дети непосредственно связывают с понятием «семья». Таким образом, дети косвенно сообщают нам, что родители обеспечивают им безопасность, а семья, по выражению А. Тоффлера, выступает «зоной стабильности» (Тоффлер, 1997: 306). Зависимое положение детей признается ими, а положительное социально-психологическое самочувствие детей непосредственно связано с фактором наличия семьи. Они осознают, что семья является необходимым условием благополучия детей и взрослых. Однако дети вполне осознают свое зависимое положение и необходимость в заботе. Аети были единодушны, утверждая необходимость семьи для ребенка независимо от материального положения их семей:

Вопрос: "Аля чего нужна семья? Можно обойтись без семьи?"

Никита (А): «Аучше жить семьей, потому что дети не могут варить обед...»

Вова (A): «...дети не могут покупать сами».

Аеня (B): «Вместе дружно».

Юля (B): «В одиночку ребенку страшно. С родителями смелее и смешнее».

Аня (В): «Чтобы взрослые готовили детям кушать, а когда ребенок маленький ходили с коляской, кормили, заботились».

Александр (C): «Когда ты одинок, у тебя друзей нет».

Аиза (С): «Надо семьей жить. Потому что, если мама одна будет жить, ей тяжело будет ребенка вырастить».

Социальная дифференциация положения детей и их семей выразилась в вопросах о наличии друзей, их круге общения и возможности совместного проведения свободного времени. Аети, проживающие в центральной части города, имеют друзей в основном только в детском саду либо в других детских учреждениях, которые они посещают (музыкальные, художественные, танцевальные и спортивные школы, школы иностранных языков и т. д.). Контакты со сверстниками ограничены в связи с загруженностью образовательной деятельностью, которую регламентируют и контролируют взрослые. Аети из группы В и группы С добавили к друзьям, приобретенным в детском саду, также сверстников из соседей по месту проживания. Вне посещения детского сада они завязывают дружеские отношения с соседскими детьми, с которыми могут совместно играть в домашних условиях либо на прогулках у дома. Существенной разницей в вопросе формирования дружеских отношений между детьми группы В и группы C является сопровождение (присутствие) взрослых в период детского общения. Аетей группы B, как правило, сопровождают взрослые. Аетям группы C взрослые позволяют свободно общаться вне своего поля зрения. 
Bonрос: «У вас есть друзья? Как вы с ними дружите?»

Максим (A): «У меня много друзей там, где меня учат плавать».

Никита (А): «Я взрослый, поэтому у меня и друзья большие».

Карина (А): «У меня подруга Ангелина, мы с ней играем в парикмахерскую. А дома я играю с собачкой».

Сергей (B): «У меня много друзей. Возле дома мы играем в футбол».

Ангелина (B): «А мы с Аашей дома и в детском саду дружим. У нас и мамы дружат, мы вместе гуляем».

Екатерина (В): «У меня есть подруги здесь и на танцах, еще мы вместе гуляем».

Иван $(\mathrm{C})$ : «У меня много друзей, Коля и Толя старше меня. Но мне интересно с ними. Меня даже мама отпускает с ними гулять».

$\Lambda$ ера (C): «Я живу рядом с Анной. Мы дружим в детском саду и дома».

Анна (C): «Нас даже родители отпускают вместе гулять возле дома. Иногда они нам телефон дают, чтобы мы звонили».

Евгения $(\mathrm{C})$ : «А я тоже гуляю возле дома с девочками. За мной родители смотрят в окно. Но мы иногда играем “в прятки”, и родители нас не видят».

Современные информационные технологии внесли свой вклад в основной вид детской деятельности - игру. Игра, имеющая своей целью быть для ребенка прообразом жизни взрослых, полигоном для моделирования и отработки социальных ролей в обществе, как форма упражнения непосредственного взаимодействия детей, уступает свои позиции компьютерным играм. На вопрос об играх и любимых занятиях дети в эпоху господства информационных технологий, безусловно, в большинстве ответов называли игру компьютерного характера. Однако были и дети, которые продемонстрировали интерес к играм конструкторского характера, предметным (конструкторы, кукды, транспорт, имитация домашнего интерьера, предметов обихода и т. А.), игрушкам с дистанционным управлением и подвижным играм. Аети из группы А в большинстве случаев выбирали компьютерные игры и игрушки с дистанционным управлением, которые относятся к дорогостоящему сегменту товаров.

Bопрос: «B какие игры вы любите играть?"

Николай (А): «Я люблю играть в компьютер, их там много, они все разные».

Вова (A): «Я люблю играть с машинками на пульте. Их у меня три, и еще есть вертолет на пульте».

София (А): «А у меня есть кукла Ренни, она все умеет делать, и еще у меня есть большой дом для нее, в нем все есть, как у нас».

Петр (В): «Я люблю играть в футбол. Я буду футболистом».

Иеонид (B): «Я люблю играть с братом в гараж с машинками. Мы его строим из конструктора».

Юлия (В): «Я люблю играть с Барби и в ее дом».

Борис (C): «Я люблю кататься на велосипеде».

Александр (C): «Я люблю играть с машинками, я водитель спортивной машины».

Елизавета (C): «Я люблю играть в прятки».

Варвара $(\mathrm{C})$ : «У меня есть много Барби, я с ними играю, кормлю, одеваю».

\section{МНОГООБРАЗИЕ ПОВСЕАНЕВНЫХ СОЦИААЬНЫХ ПРАКТИК АЕТЕЙ}

Проведенное исследование среди детей, принадлежащих к различным социальноэкономическим слоям, продемонстрировало детерминированность социальных практик в повседневной жизни детей, различие в содержании их жизненного мира и как 
следствие в сущности феномена детства как антиномии взрослости. Формирование представлений о «детстве - взрослости» у детей имеет двойственный и противоречивый характер, так как, с одной стороны, взрослые из непосредственного окружения подчеркивают, что дети повзрослели или, наоборот, еще являются детьми, а с другой стороны - практика предоставления полномочий, освобождения из-под взрослого надзора не соответствует декларируемому ими (взрослыми) возрастному периоду.

Особенно данное несоответствие выражено в рассмотренных группах А и С. Так, дети группы А уверенно сначала представляют себя повзрослевшими, ссылаясь при этом на мнение родителей и других людей из взрослого окружения, однако дальнейшие ответы показали, что в действительности жизнь детей из социально-экономического слоя с высоким уровнем дохода и высокими стандартами жизни часто проходит в жестко контролируемом и регламентируемом социальном пространстве, где отсутствует возможность для проявления инициативы и активности, которое необходимо Аля формирования собственной и ответственной позиции «не ребенка». А дети группы С идентифицировали себя с детским сообществом, но характер проведения досуга и формирования взаимоотношений с социумом показал наличие высокого уровня самостоятельности и отсутствие пристального контроля со стороны взрослых. Пристальный присмотр (например, приглашение к сотрудничеству гувернанток) и участие в жизни ребенка связаны на первый взгляд с высокой занятостью родителей и финансовыми возможностями как результатами профессиональной деятельности.

Однако сопоставление занятости родителей и соотношение самоидентификации к детскому сообществу, степень проявления их активности по результатам ответов детей группы В показывают, что гармоничное формирование самопричисления себя к миру детства происходит на фоне разумного присутствия взрослых в детском мире. Эта разумность проявляется в умеренной вовлеченности в детскую жизнь, в позиции взрослого "рядом», которая придает уверенности во взаимодействии со сверстниками, друзьями, позволяет скоординировать инициативу ребенка. Заметим, что у детей из группы В в основном оба родителя работают в отличие от групп А и С, где работает чаще всего один из родителей. Поэтому характер занятости родителей не является ключевым в формировании гармоничной самоидентификации и освоения социальных ролей и дальнейшего развертывания социального взаимодействия в обществе.

Социально-экономическая характеристика возможностей и жизни семьи отражается и на представлениях детей о знаковых событиях, сопровождающих переход детей в жизнь взрослых. Аля детей группы А эти события носят атрибутивный характер и не являются результатом собственной активности и достижений. А для детей групп А и С эти события носят деятельностный и результирующий характер.

Различие в жизнедеятельности детей в зависимости от социально-экономических факторов жизни семьи выражается в организации их игровой деятельности. Аети из обеспеченных слоев играют в основном в игрушки, функционал которых не требует взаимодействия с другими детьми. Эти игрушки интерактивны сами по себе, но, к сожалению, не обеспечивают возможность освоения и распределения социальных ролей с другими участниками игры как инструмент формирования моделей взаимодействия в обществе. Аанная особенность игровой деятельности соответствует, согласно Аж. Г. Миду, стадии индивидуальных игр (play stage), а не коллективных игр (game stage) (см.: Козер, 2013: 267), во время которых происходит освоение социальных ролей, что актуально в данный период жизни детей. Аля детей из обеспеченных семей характерен широкий круг общения, но в большей мере он состоит из взрослых людей 
(родных, друзей и приятелей родителей), а общение с детьми ограничено рамками закрытостью социального слоя. Аети же из менее обеспеченных слоев чаще вовлечены в широкое взаимодействие с другими детьми, в том числе благодаря организации игровой деятельности и условиям формирования дружеских отношений.

Аети всех групп единодушны в том, что взрослая жизнь отличается наличием полномочий и свободным выбором деятельности, отсутствием ограничений. Также дети едины во мнении о том, что комфорт детской жизни обеспечивается семьей, заботой родителей, что они не в состоянии без родительской поддержки интегрироваться в жизнь общества.

Таким образом, разнообразие современных условий жизни индивидов формирует множественный характер повседневности детей, создавая таким образом «множественность» (Кон, 2003: 68) образов «детства» как этапа жизненного пути, предшествующего также многоликой «взрослости».

\section{ЗАКАЮЧЕНИЕ}

В целом исследование показало, что социально-экономическое положение семьи, условия проживания ребенка, особенности его социализации и характер взаимодействия с взрослыми отражаются на формировании представлений детей о «детстве» и «взрослости». У детей складываются представления о том, что переход из детства во взрослую жизнь сопряжен с некоторыми событиями инициации, а содержание этих возрастных периодов отличается характером деятельности и коммуникаций. Суждения детей строятся на возможностях, которые предоставляют им взрослые, на деятельности, в которую вовлечены и в которой себя реализовывают дети. Предоставляемые возможности для самореализации формируют собственное «Я» ребенка, его самооценку себя и событий, проводят дифференциацию между социальными плоскостями.

Аетство является тем периодом жизни человека, который на протяжении истории человечества менял возрастные границы и социальный смысл в зависимости от уровня развития общества и идеалов и ценностей, господствовавших в нем. Осмысление детства как возраста со своим функциональным значением происходит на фоне дифференциации или его антагонизма другим возрастным этапам жизни человека: детство - это не взрослость и не зрелость, детство предшествует взрослости. Поэтому осознание и содержательное наполнение возрастного периода «детства» находится в прямой зависимости от понимания «взрослости». В предыдущие эпохи, когда в обществе было принято прибегать к обрядам инициации, человек ясно представлял свою принадлежность к возрастной структуре общества с соответствующими последствиями социального характера и «созданием новой знаковой реальности» (Бочаров, 2000: 94). В современном обществе индивидуальные сценарии возрастных трансформаций обусловлены социально-экономической принадлежностью индивида, культурной символикой, бытующими в его социальной среде критериями взрослости и соответствующим личным проявлением деятельности, или, как называл А. Н. Узнадзе, «возрастной средой», которая окружает ребенка с момента рождения и указывает на его возрастную принадлежность и возрастные полномочия (Узнадзе, 2013: 123). Выявленные противоречия в социальной реальности повседневной жизни детей, в понимании ими возрастной дифференциации и своей интеграции в нее являются предшествием в вопросах формирования идентичности и проблем, связанных с инфантилизацией современного молодого поколения. Современное общество особенно демонстрирует 
нам «множественность» детских миров, возрастных границ детства. А предположения Н. Постмана (Современный ребенок ..., 2006: 33) оказываются правомерными хотя бы только потому, что детство закономерно увеличивает свои границы, а взрослость преждевременно вторгается в детство, сокращая его возрастные границы и стирая специфические различия. Поэтому антагонистический характер дихотомии «детство - взрослость» преобразуется в феномены «детство во взрослости» и «взрослость в детстве», отражающие множественность событий и детских социальных практик.

\section{ПРИМЕЧАНИЯ}

1 В дополнение к результатам проведенного исследования хотелось бы добавить, что дети как участники фокус-группы проявили большой интерес к мероприятию и высказали пожелание еще раз встретиться, чтобы «с ними поговорили о них». Поэтому автору хотелось бы выразить глубокую признательность детям за искренность, а также их родителям за доверие, а персоналу дошкольных воспитательных учреждений за помощь в организации.

2 Буквы А, В или С после имени ребенка обозначают принадлежность его соответственно к группам $\mathrm{A}, \mathrm{B}$ или $\mathrm{C}$.

\section{СПИСОК АИТЕРАТУРЫ}

Арьес, Ф. (1999) Ребенок и семейная жизнь при Старом порядке : пер. с фр. Екатеринбург : Иза-во Уральск. ун-та. 416 с.

Бауман, 3. (2008) Текучая современность : пер. с англ. СПб. : Питер. 240 с.

Безрогов, В. Г. (2007) Аетство и дети в Европе и Америке XVI-XVIII веков: новые зарубежные исследования // Человек. № 4. С. 183-189.

Бесчасная, А. А. (2007) Аетство: история и современность. СПб. : Нестор-История. 184 с.

Бочаров, В. В. (2000) Антропология возраста. СПб. : Изд-во С.-Петерб. ун-та. 192 с.

Васильева, Н. А. (2006) Аетский психоанализ. СПб. : Изд-во С.-Петерб. ун-та. 254 с.

Гидденс, Э. (2004) Трансформация интимности: сексуальность, любовь и эротизм в современных обществах : пер. с англ. СПб. : Питер. 208 с.

Аемоз, А. (2000) Психоистория : пер. с фр. Ростов-на-Аону : Феникс. 512 с.

Емельянова, Т. П. (2015) Психологическое благополучие и социальные представления о жизни в мегаполисе // Знание. Понимание. Умение. № 1. С. 213-223. DOI: 10.17805/zpu.2015.1.20

Козер, А. А. (2013) Мастера социологической мысли. Идеи в историческом и социальном контексте / под ред. И. Б. Орловой ; пер. с англ. Т. И. Шумилиной. СПб. : Нестор-История. $464 \mathrm{c.}$

Кон, И. С. (2003) Ребенок и общество. М. : Изд. центр «Академия». 336 с.

Аеонтьев, А. Н. (1984) Потребности, мотивы и эмоции // Психология эмоций : тексты / под ред. В. К. Вилюнаса, Ю. Б. Гиппенрейтер. М. : Изд-во Моск. ун-та. 288 с. С. 162-171.

Современный ребенок. Энциклопедия взаимопонимания (2006) / под ред. А. Я. Варги. М. : ОГИ ; Фонд научных исследований «Прагматика культуры». 640 с.

Солнышков, А. Ю. (2014) Субъективная реальность и проблемы ее теоретического моделирования // Знание. Понимание. Умение. № 3. С. 157-166.

Фельдштейн, А. И. (2004) Психология взросления: структурно-содержательные характеристики процесса развития личности : Избранные труды. 2-е изд. М. : Моск. психол.-соц. ин-т ; Флинта. 670 с.

Фоломеева, Т. В. (2003) Использование проективных методик для повышения эффективности фокус-групп // Социология: 4М. №17. С. 83-108.

Тоффлер, А. (1997) Футурошок : пер. с англ. СПб. : Аань. 464 с.

Узнадзе,А. Н. (2013) Периодизация детского возраста // Культурно-историческая психология. № 3. С. 121-124. 
Breland-Noble, A. M. (2014) Parenting across diverse contexts // Journal of Child and Family Studies. Vol. 23. Issue 2. P. 173-176. DOI 10.1007/s10826-013-9898-8

Аата поступления: 6.07.2015 г.

THE DICHOTOMY OF 'CHILDHOOD' AND 'ADULTHOOD' AS VIEWED BY CHILDREN (IN THE CONTEXT OF SOCIAL AND ECONOMIC STATUS OF THEIR PARENTAL FAMILIES)

\section{A. A. BESCHASNAYA}

(St. Petersburg State University of Architecture and Civil Engineering)

The contemporary society is marked by its fast-moving and conflicting processes and phenomena. Childhood, like many other contemporary social phenomena, is subject to change due to a number of factors. Childhood as a period of age preceding adulthood occurs as a result of cultural and historical factors. Specific socio-psychological features of an individual are first shaped in childhood and then undergo age-related psychological crises and are transferred into adult life. The transition from childhood to adulthood is not a single-step process. Every path of growing up is personal and depends on various life circumstances. Among the factors which determine an individual vision of childhood, the nature of age-related crises and the transition to adulthood, are the social and economic family status, peculiarities of upbringing and socialization in the family.

In this article, the author looks at childhood in the social and economic context through the eyes of children - as a dichotomic pair of adulthood. This comparative study of childhood and adulthood examined the views of children brought up in families with different levels of material well-being. In 2007, the author carried out a social and psychological study of 6- and 7-year-old children in St. Petersburg. The focus groups showed that children's judgements of childhood and their vision of adulthood are determined by social and economic well-being of their families. Socioeconomic conditions as a factor of socialization influenced children's representations and helped model their 'lifeworld' at present and in future. Children's responses revealed that others have an ambivalent attitude to them. Therefore, children's perceptions of themselves as the representatives of 'childhood' or 'adulthood' bring together elements of various everyday social practices - game activities, interaction with peers and with the older generation, as well as the informational content of communication.

Children who do not experience socio-economic disadvantage are more prone to a dissonance in self-identification vis-?-vis the world of children and the adult world. They find themselves at the epicenter of a contradiction: they are characterized as 'adults', but at the same time their activities and communicative space for self-realization are limited. The everyday life of children from other socioeconomic strata includes social practices where adult control is reduced or lacking, which can also lead to contradictions in children's self-identification.

Keywords: childhood; adulthood; children; focus group; family; socioeconomic factor

\section{REFERENCES}

Aries, F. (1999) Rebenok i semeinaia zhizn' pri starom poriadke [Centuries of childhood: A social history of family life]/ transl. from French. Ekaterinburg, Ural University Pub. 416 p. (In Russ.).

Bauman, Z. (2008) Tekuchaia sovremennost' [Liquid modernity] / transl. from English. St. Petersburg, Piter Publ. 240 p. (In Russ.).

Bezrogov, V. G. (2007) Detstvo i deti v Evrope i Amerike XVI-XVIII vekov: novye zarubezhnye issledovaniia [Childhood and children in Europe and America in the 16th-18th centuries: new foreign research]. Chelovek, no. 4, pp. 183-189. (In Russ.).

Beschasnaya, A. A. (2007) Detstvo: istoriia i sovremennost' [Childhood: History and modern times]. St. Petersburg, Nestor-Istoriia Publ. 184 p. (In Russ.).

Bocharov, V. V. (2000) Antropologiia vozrasta [Anthropology of age]. St. Petersburg, St. Petersburg University Publ. 192 p. (In Russ.).

Vasilieva, N. L. (2006) Detskii psikhoanaliz [Psychoanalysis of children]. St. Petersburg, St. Petersburg University Publ. 254 p. (In Russ.). 
Giddens, A. (2004) Transformatsiia intimnosti: seksual'nost', liubov' i erotizm v sovremennykb obshchestvakb [The transformation of intimacy: Sexuality, love, and eroticism in modern societies] / transl. from English. St. Petersburg, Piter Publ. 208 p. (In Russ.).

DeMause, L. (2000) Psikboistoriia [Foundations of psychohistory]/ transl. from French. Rostovon-Don, Feniks Publ. 512 p. (In Russ.).

Emelianova, T. P. (2015) Psikhologicheskoe blagopoluchie i sotsial'nye predstavleniia o zhizni $\mathrm{v}$ megapolise [Psychological well-being and social representations of life in the city]. Znanie. Ponimanie. Umenie, no. 1, pp. 213-223. (In Russ.). DOI: 10.17805/zpu.2015.1.20

Coser, L. A. (2013) Mastera sotsiologicheskoi mysli. Idei v istoricheskom $i$ sotsial' nom kontekste [Masters of sociological thought: Ideas in historical and social context]/ ed. by I. B. Orlova; transl. from English by T. I. Shumilina. St. Petersburg, Nestor-Istoriia Publ. 464 p. (In Russ.).

Kon, I. S. (2003) Rebenok $i$ obshchestvo [Child and society]. Moscow, Akademia Publ. Center. 336 p. (In Russ.).

Leontiev, A. N. (1984) Potrebnosti, motivy i emotsii [Needs, motives and emotions]. In: Psikbologiia emotsii. Teksty [Psychology of emotions. Texts]/ ed. by V. K. Viliunas and Yu. B. Gippenreiter. Moscow, Moscow University Publ. 288 p. Pp. 162-171. (In Russ.).

Sovremennyi rebenok. Entsiklopediia vzaimoponimaniia [The modern child. An encyclopedia of mutual understanding] (2006) / ed. by A. Varga. Moscow, OGI ; Fond nauchnykh issledovanii "Pragmatika kul'tury". 640 p. (In Russ.).

Solnyshkov, A. Yu. (2014) Sub'ektivnaia real'nost' i problemy ee teoreticheskogo modelirovaniia [Subjective reality and problems of its theoretical modeling]. Znanie. Ponimanie. Umenie, no. 3, pp. 157-166. (In Russ.).

Feldshtein, D. I. (2004) Psikbologiia vzrosleniia: strukturno-soderzhatel'nye kbararkteristiki protsessa razvitiia lichnosti [Psychology of growing up: Structural and content-related characteristics of personality development]: Selected works. 2nd edn. Moscow, Moscow Psychological and Social Institute Publ. ; Flinta Publ. 670 p. (In Russ.).

Folomeeva, T. V. (2003) Ispol'zovanie proektivnykh metodik dlia povysheniia effektivnosti fokusgrupp [The use of projective techniques to increase efficiency of focus groups]. Sotsiologiia: 4M, no. 17, pp. 83-108. (In Russ.).

Toffler, A. (1997) Futurosbok [Future shock] / transl. from English. St. Petersburg, Lan' Publ. 464 p. (In Russ.).

Uznadze, D. N. (2013) Periodizatsiia detskogo vozrasta [The periodization of childhood]. Kul'turno-istoricheskaia psikbologiia, no. 3, pp.121-124. (In Russ.).

Breland-Noble, A. M. (2014) Parenting across diverse contexts. Journal of Child and Family Studies, vol. 23, issue 2, pp. 173-176. DOI 10.1007/s10826-013-9898-8

Submission date: 6.07.2015.

Бесчасная Альбина Ахметовна - кандидат социологических наук, доцент, доцент кафедры философии, политологии и социологии Санкт-Петербургского государственного архитектурно-строительного университета; член Российского общества социологов; член Аома ученых им. М. Горького РАН. Адрес: 190005, Россия, г. Санкт-Петербург, ул. 2-я Красноармейская, А. 4. Тел.: +7 (812) 316-58-72. Эл. адрес: aabes@inbox.ru

Beschasnaya Albina Akhmetovna, Candidate of Sociology, Associate Professor, Department of Philosophy, Politology and Sociology, St. Petersburg State University of Architecture and Civil Engineering; Member, Russian Society of Sociologists; Member, Gorky House of Scientists, Russian Academy of Sciences. Postal address: 4 Vtoraya Krasnoarmeyskaya St., 190005 St. Petersburg, Russian Federation.Tel.: +7(812) 316-58-72.E-mail: aabes@inbox.ru 